\title{
Phylogenetic analysis of Ukrainian Bacillus anthracis strains from various sources
}

\author{
Oleksandr V. Biloivan ${ }^{1}$, Angela Duerr ${ }^{2}$, Julia Schwarz ${ }^{3}$, Vasiliy Arefev ${ }^{1}$, Oleksii Solodiankin ${ }^{1}$, \\ Borys Stegniy ${ }^{1}$, Anton Gerilovych ${ }^{1}$
}

${ }^{1}$ Laboratory of Molecular Diagnostics, National Scientific Center "Institute of Experimental and Clinical Veterinary Medicine", Kharkiv, Kharkivska oblast, Ukraine, ${ }^{2}$ Bundeswehr Institute of Microbiology, Munich, Bavaria, Germany, ${ }^{3}$ Bundeswehr Institute of Microbiology, Munich, Bavaria, Germany

\section{Objective}

Due to the lack of information about the phylogenetic origins of Ukrainian Bacillus anthracis strains, the goal of this work was to make phylogenetic analysis of Ukrainian isolates obtained from various sources (soil, clinical material from infected humans and animal products) for better understanding of phylogenetic origins of this pathogen in Ukraine and Eastern Europe.

\section{Introduction}

Anthrax is a widely spread zoonotic disease with natural transmissive cycle involving wildlife, livestock and humans [1]. It is caused by Bacillus anthracis, a highly pathogenic gram-positive, spore-producing bacterium, which poses a serious threat to public and animal health due to its mortality both for animals and for humans [2-4]. The ability of B. anthracis spores to remain viable in soils for decades enables their isolation from freely accessible environment [5]. This unique feature to form highly resistant spores in the environment plays a major role in the ecology and evolution of this pathogen [6]. During the spore phase, evolution is greatly reduced in rate, which limits the amount of genetic diversity found among isolates of this species [1]. All these factors demonstrate the need for reliable anthrax diagnosis and trace-back methods. This comprises bio forensic capabilities including state-of-the-art methods for accurate genotyping of $B$. anthracis strains.

\section{Methods}

23 thermolysates of $B$. anthracis broth cultures isolated from various sources (vesicles from eleven different people infected with cutaneous anthrax when disease's sporadic outbreaks were detected in Ukraine in 1963-2002, as well as two samples from sheep wool, and eight soil samples) were obtained from the Central Epidemiological Station (Kyiv, Ukraine), as well as from I.I. Mechnikov Ukrainian Scientific and Research Anti-plaque Institute (Odessa, Ukraine). These anthrax cultures were confirmed with classical microbiological methods (microscopy, cultivation on solid and liquid media), "string of pearls" reaction, and using bioassay on living white mice (the mortality was observed two days after subcutaneous injection of 0,2-0,5 ml of cells' suspension). All these tests were carried out at the institutions where samples were obtained. Besides, one B. anthracis isolate was cultivated from soil sample of an animal grave site nearby Koviagy village, Valky district, Kharkiv region. All samples were analyzed at the Bundeswehr Institute of Microbiology (Munich, Germany). To confirm the presence of the anthrax genome and plasmids, we isolated genomic DNA (gDNA) from thermolysates and studied the presence of the genomic marker dhp61 as well as the plasmid specific marker pagA (pXO1) and $\operatorname{cap} C$ (pXO2) using qPCR. Quality of the isolated gDNA was tested using the Agilent bioanalyzer. To characterize regional and global phylogeographic patterns of these strains, canonical Single Nucleotide Polymorphisms analysis (canSNP) was conducted using high resolution melt (HRM). Three thermolysates of broth cultures isolated and soil sample isolated from animal grave site in Kharkiv region were analyzed using NewSeq Full genome sequencing.

\section{Results}

B. anthracis chromosomal DNA-marker $d h p 61$ as well as pXO1 marker pagA and pXO2 plasmid marker capC could be detected in all thermolysates. However, the soil isolate from the Koviagy grave site was positive for dhp61 but contained only the pXO1 plasmid. The Bioanalyzer assay revealed that only 6 out of the 23 thermolysates had good enough DNA quality to be sequenced. So far only genomes of thermolysates of soil samples from Mykolaiv and Sumy regions, the thermolysate of sick patient's vesicle from Kherson region as well as the soil sample from the animal grave site in Kharkiv region have been sequenced. For the residual 3 thermolysates the full genome analysis is still in progress. The sequencing results showed that the B. anthracis strain isolated from Mykolaiv soil sample belongs to the Vollum linage group and other thermolysates from Sumy and Kherson regions are closely

SDS Annual Conference Proceedings 2019. This is an Open Access article distributed under the terms of the Creative Commons AttributionNoncommercial 4.0 Unported License (http://creativecommons.org/licenses/by-nc/3.0/), permitting all non-commercial use, distribution, and reproduction in any medium, provided the original work is properly cited. 
clustering with isolates from Japan. Thus, human isolate from Kherson region is clustering with the Japanese isolate BA104 which was obtained from pig during sporadic anthrax incident in 1982 and soil isolate from Sumy region is clustering with the BA 103 isolate which was obtained from beef cattle in Japan in 1991. In contrast, we analyzed the genomic sequence of the pXO2-negative isolate from grave site in Kharkiv region using BioNumerics software and found that it has high similarity to STI strain.

\section{Conclusions}

The infrequent sporadic occurrence of anthrax in the country of Ukraine is likely caused by a heterogeneous population of $B$. anthracis. The found STI strain in the grave site of Kharkiv region is probably an environmental recovery of the Russian anthrax live vaccine which was commonly used for vaccination of animals in the former Soviet Union The sequencing result of the soil isolate from Mykolaiv region indicates the occurrence of another canSNP group, the Vollum group, which is quite untypical for Ukraine. The latter is mainly prevalent in the Asian regions (namely Pakistan) and therefore might have been introduced to Ukraine over the silk road. Other two thermolysates from Sumy and Kherson regions also showed unexpected results clustering with Japanese isolates. The further research of Ukrainian B. anthracis isolates will allow us to expand our knowledge about the population structure and evolution of anthrax in Ukraine.

\section{Acknowledgement}

Special thanks to:

1. My scientific supervisor, director of NSC "IECVM", doctor of veterinary sciences, professor, NAAS academician, Borys Tymofiyovych Stegniy;

2. Colleagues from Bundeswehr Institute of Microbiology for strong material and methodological support in this research;

3. Partners from Deutsche Gesellschaft für Internationale Zusammenarbeit (GIZ) company for organization of this research project in frames of German Biosecurity Program;

4. Colleagues from the Central Epidemiological Station (Kyiv, Ukraine) and I.I. Mechnikov Ukrainian Scientific and Research Anti-plaque Institute (Odessa, Ukraine) for providing of samples for research.

\section{References}

1. Van Ert MN, Easterday WR, Huynh LY, Okinaka RT, Hugh-Jones ME, et al. 2007. Global Genetic Population Structure of Bacillus anthracis. PLoS One. 2(5), e461. PubMed https://doi.org/10.1371/journal.pone.0000461

2. Freidlander AM. 1997. Anthrax, p. 467-478. In F. R. Sidell, E. T. Takafuji, and D. R. Franz (ed.), Medical aspects of chemical and biological warfare. Office of the Surgeon General, Washington, D.C.

3. Hoffmaster AR, Fitzgerald CC, Ribot E, Mayer LW, Popovic T. 2002. Molecular subtyping of Bacillus anthracis and the 2001 bioterrorism-associated anthrax outbreak, United States. Emerg Infect Dis. 8, 1111-16. PubMed https://doi.org/10.3201/eid0810.020394

4. Keim P, Van Ert MN, Pearson T, Vogler AJ, Huynh LY, et al. 2004. Anthrax molecular epidemiology and forensics: using the appropriate marker for different evolutionary scales. Infect Genet Evol. 4, 205-13. PubMed https://doi.org/10.1016/j.meegid.2004.02.005

5. Eitzen EM. 1997. Use of biological weapons, p. 437-450. In F. R. Sidell, E. T. Takafuji, and D. R. Franz (ed.), Medical aspects of chemical and biological warfare. Office of the Surgeon General, Washington, D.C.

6. Biloivan O, Duerr A, Schwarz J, Grass G, Arefiev V, et al. (2018) Phylogenetic analysis of Ukrainian Bacillus anthracis strains. Third Annual BTRP Ukraine Regional One Health Research Symposium, abstract directory: 122. 